Ioan-Iovitz Popescu, Mihaiela Lupea, Doina Tatar and Gabriel Altmann Quantitative Analysis of Poetic Texts 


\section{Quantitative Linguistics}

Editors

Reinhard Köhler Gabriel Altmann Peter Grzybek

Advisory Editor Relja Vulanović

\section{Volume 67}


Ioan-lovitz Popescu, Mihaiela Lupea, Doina Tatar and Gabriel Altmann Quantitative Analysis of Poetic Texts 
ISBN 978-3-11-033605-4

e-ISBN (PDF) 978-3-11-036379-1

e-ISBN (EPUB) 978-3-11-039479-5

ISSN 0179-3616

\section{Library of Congress Cataloging-in-Publication Data}

A CIP catalog record for this book has been applied for at the Library of Congress.

Bibliographic information published by the Deutsche Nationalbibliothek

The Deutsche Nationalbibliothek lists this publication in the Deutsche Nationalbibliografie; detailed bibliographic data are available on the Internet at http://dnb.dnb.de.

(C) 2015 Walter de Gruyter GmbH, Berlin/Boston

Printing and binding: CPI books $\mathrm{GmbH}$, Leck

(2) Printed on acid-free paper

Printed in Germany

www.degruyter.com 